\title{
ISOFORM EXPRESSION IN THE MULTIPLE SOLUBLE MALATE DEHYDROGENASE OF Hoplias malabaricus (ERYTHRINIDAE, CHARACIFORMES)
}

\author{
AQUINO-SILVA, M. R., ${ }^{1}$ SCHWANTES, M. L. B. ${ }^{2}$ and SCHWANTES, A. R. ${ }^{2}$ \\ ${ }^{1}$ Universidade do Vale do Paraíba, FEAU, Avenida Shishima Hifumi, 2911, CEP 12010-400, \\ São José dos Campos, SP, Brazil \\ ${ }^{2}$ Universidade Federal de São Carlos, Departamento de Genética e Evolução, C.P. 676, \\ CEP 13565-905, São Carlos, SP, Brazil \\ Correspondence to: Maria Regina de Aquino-Silva, Universidade do Vale do Paraíba, FEAU, Avenida Shishima \\ Hifumi, 2911, CEP 12010-400, São José dos Campos, SP, Brazil, e-mail: mreginaquino@aol.com \\ Received January 23, 2002 - Accepted May 6, 2002 - Distributed February 28, 2003
}

(With 4 figures)

\begin{abstract}
Kinetic properties and thermal stabilities of Hoplias malabaricus liver and skeletal muscle unfractionated malate dehydrogenase (MDH, EC 1.1.1.37) and its isolated isoforms were analyzed to further study the possible $s M D H-A *$ locus duplication evolved from a recent tandem duplication. Both A (A1 and A2) and B isoforms had similar optima $\mathrm{pH}$ (7.5-8.0). While Hoplias A isoform could not be characterized as thermostable, B could as thermolabile. A isoforms differed from B isoform in having higher $\mathrm{Km}$ values for oxaloacetate. The possibly duplicated A2 isoform showed higher substrate affinity than the A1. Hoplias duplicated A isoforms may influence the direction of carbon flow between glycolisis and gluconeogenesis.
\end{abstract}

Key words: isoforms, sMDH, Hoplias malabaricus, recent locus duplication.

\section{RESUMO}

\section{A malato desidrogenase solúvel de Hoplias malabaricus (Erythrinidae, Characiformes)}

A fim de avaliar uma possível duplicação gênica recente no loco $s M D H-A *$ de Hoplias malabaricus, foram analisadas as propriedades eletrocinéticas, cinéticas e de termoestabilidade da malato desidrogenase, estudando-se extratos brutos de fígado e de músculo esquelético, assim como de suas diferentes isoformas isoladas. $\mathrm{O}$ efeito do $\mathrm{pH}$ sobre a atividade da $\mathrm{sMDH}$ mostrou $\mathrm{pH}$ ótimo semelhante para as isoformas A (A1 e A2) e B (7.5-8.0). Testes cinéticos de termoestabilidade em H. malabaricus mostram que as isoformas A são mais termoestáveis que as B, mas seus valores de meia-vida não as caracterizam como termoestáveis. Já a isoforma B, pelo valor de meia-vida apresentado, é caracterizada como termolábil. Quanto aos valores de $K \mathrm{~m}$ para oxalacetato, as isoformas A diferem da isoforma B por apresentarem maiores valores. A presença de duplicação gênica no loco $-A$, com a isoforma $\mathrm{A} 2$ apresentando maior afinidade com o substrato que a isoforma A1, poderia conferir a essa espécie maior eficiência no processo de redução do oxalacetato a malato, favorecendo o metabolismo no sentido glicolítico.

Palavras-chave: isoformas, sMDH, Hoplias malabaricus, duplicação lócica recente.

\section{INTRODUCTION}

Soluble dimeric malate dehydrogenase $(\mathrm{MDH}$, EC 1.1.1.37) is encoded at two loci $-s M D H-A^{*}$ and $s M D H-B^{*}$, which results in a three-banded electrophoretic pattern (A2, $\mathrm{AB}$ and $\mathrm{B} 2)$ present in most fish and amphibian species studied (Bailey et al., 1969; Schwantes \& Schwantes, 1977, 1982a, b; De Luca et al., 1983; Coppes et al., 1987; FenerichVerani et al., 1990; Monteiro et al., 1991, 1998; Farias \& Almeida-Val, 1992; Lin \& Somero, 1995a, b; Caraciolo et al., 1996; Aquino-Silva et al., 1997). 
The subtropical teleost Hoplias malabaricus (Erytrhinidae, Characiformes), studied by Monteiro et al. (1991, 1998), showed a six-banded pattern for sMDH. To explain this pattern these authors suggested a recent locus duplication of $s M D H-A^{*}$ in addition to its $s M D H-B^{*}$. Since there is no evidence of polyploidy in the Erythrinidae family (Bertollo et al., 1986), and both A-isoforms exhibited a non-divergent pattern of expression and thermostability (Monteiro et al., 1991, 1998; Aquino-Silva et al., 1997) this pattern was explained as the result of regional duplication ("in tandem") occurring at the $s M D H-A^{*}$. While these $s M D H-A^{*}$ loci encode nondivergent thermostable isoforms, the $s M D H-B^{*}$ encodes a thermolabile one. Adaptation to temperature by the two soluble $\mathrm{MDH}$ gene loci of teleost fish, where $s M D H-A^{*}$ encodes a thermostable and $s M D H-B *$ a thermolabile isoform was shown by Schwantes \& Schwantes (1982a, b), De Luca et al. (1983), Coppes et al. (1987), Monteiro et al. (1991, 1998), Farias \& AlmeidaVal (1992), and Lin \& Somero (1995a, b).

In a previous paper (Aquino-Silva et al., 1997) comparing the effect of temperature-pH on liver, muscle and heart unfractionated sMDH of Hoplias, we examined the responses of their apparent $\mathrm{Km}$ of oxaloacetate to three temperature assays $\left(10^{\circ}, 20^{\circ}\right.$ and $\left.30^{\circ} \mathrm{C}\right)$ and two $\mathrm{pH}$-regimens (temperature-dependent $\mathrm{pH}$ and constant-pH imidazole buffer). Liver extracts contributions of duplicate-A thermostable (A1 and A2) and B thermolabile subunits to the isozymes as estimated by Klebe's (1975) method were 16:1, showed the highest $K \mathrm{~m}$ values, the minimum $K \mathrm{~m}$ being obtained at $30^{\circ} \mathrm{C}$ (both $\mathrm{pH}$-regimens). On the other hand, muscle extracts whose A subunit contribution to the isozymes was the smallest among tissues analyzed ( 2 thermolabile to 1 thermostable), showed the smallest $K \mathrm{~m}$ values and minimum $K \mathrm{~m}$ at $10-20^{\circ} \mathrm{C}$ (temperature-pH dependent and constant-pH imidazole buffer, respectively).

To examine this possible recent gene duplication, the present paper describes optimum $\mathrm{pH}$, thermal stability, and Km (OXA) of total and isolated isoforms of Hoplias sMDH.

\section{MATERIAL AND METHODS}

Thirty-one specimens of $H$. malabaricus were collected by throw net from the Monjolinho Reservoir at the Federal University of São Carlos,
State of São Paulo, Brazil. Annual temperature at the $H$. malabaricus capture site ranges from $12.3^{\circ} \mathrm{C}-23.0^{\circ} \mathrm{C}$. Liver and white muscle from each individual were dissected immediately after capture and kept at $-20^{\circ} \mathrm{C}$. A small piece of each tissue was homogenized (w/v) in a $50 \mathrm{mM}$ phosphate buffer, $\mathrm{pH}$ 7.0, using a Potter-Elvejhem tissue homogenizer, and then centrifuged at $19,000 \times \mathrm{g}$ for $30 \mathrm{~min}$ at $4^{\circ} \mathrm{C}$ in a Sorvall RC5B centrifuge. Resulting crude extracts were used for electrophoretic and spectrophotometric analyses.

Electrophoreses were carried out in horizontal gels containing $14 \%(\mathrm{w} / \mathrm{v})$ corn starch prepared according to Val et al. (1981), using the pH 6.9buffer system described by Whitt (1970). A voltage gradient of $5 \mathrm{~V} / \mathrm{cm}$ was applied for $14-17 \mathrm{~h}$ at $4^{\circ} \mathrm{C}$. After electrophoresis, the starch gels were sliced lengthwise and the lower halves incubated in an MDH staining solution described by Monteiro $e t$ al. (1991). Nomenclature of sMDH gene loci, subunits and iso/allozymes was taken from Shaklee et al. (1989). lsolation of Hoplias MDH isoforms was carried out using an electrophoretic technique according to De Luca et al. (1983).

For studying $\mathrm{pH}$-activity relation, a $50 \mathrm{mM}$ sodium phosphate buffer ( $\mathrm{pH} 5.0-8.5)$ and a $0.2 \mathrm{mM}$ Tris-HCI buffer ( $\mathrm{pH}$ 9.0-9.5) were used and assays were carried out in a solution containing $0.33 \mathrm{mM}$ oxaloacetate and $0.20 \mathrm{mM}$ NADH. Crude extracts and isolated isoforms were tested for thermal stability by subjecting each sample to $50^{\circ} \mathrm{C}$, for $10-60 \mathrm{~min}$, in absence of substrate or coenzyme. The samples were then cooled on ice and centrifuged at $19.000 \mathrm{x}$ $\mathrm{g}$ for $30 \mathrm{~min}$ at $4^{\circ} \mathrm{C}$. Their residual activities were examined at $25^{\circ} \mathrm{C}$ in the direction of oxaloacetate reduction through the change in absorbance at 340 $\mathrm{nm}$ in a HP-8452A Diode Array Spectrophotometer using a temperature controlled cuvette holder. The assays were carried out in a $50 \mathrm{mM}$ imidazole chloride buffer, containing $0.33 \mathrm{mM}$ oxaloacetate and $0.20 \mathrm{mM}$ NADH. Controls were kept in an icewater mixture.

The kinetic parameters of sMDH (total and isolated isoforms) were determined at $20^{\circ} \mathrm{C}$ by measuring the oxidation of NADH spectrophotometrically at $340 \mathrm{~nm}$. The assays were carried out in a $50 \mathrm{mM}$ imidazole chloride buffer containing $0.20 \mathrm{mM} \mathrm{NADH}$ and different concentrations of oxaloacetate. Oxamate at $10 \mathrm{mM}$ was added to inhibit lactate dehydrogenase activity resulting from any pyruvate occurring in the assay 
medium. All assays were performed in triplicate and initiated by adding $10 \mu \mathrm{l}$ of enzyme (crude extract) or $100 \mu \mathrm{l}$ (isolated isoform) to $1.0 \mathrm{ml}$ of assay medium. Apparent Michaelis-Menten constants $(\mathrm{Km})$ were calculated by Lineweaver Burk method using double-reciprocal plots of velocity vs substrate concentrations.

Statistical differences among optimum $\mathrm{pH}$, thermal stability, and $K \mathrm{~m}(\mathrm{OXA})$ values of total and isolated isoforms of Hoplias sMDH were determined by the nonparametric Mann-Whitney test (Zar, 1974) with a probability level of 0.05 chosen as the limit of statistical significance.

\section{RESULTS}

Liver and muscle extracts from thirty-one $H$. malabaricus specimens confirmed the electrophoretic pattern for sMDH, which we previously obtained (Aquino-Silva et al., 1997) in fifty-five other specimens, suggesting the existence of three gene loci: $s M D H-B^{*}, s M D H-A 1^{*}$ and $s M D H-A 2 *$ (Fig. 1A). These latter could be the result of recent locus duplication since both homodimers exhibited a nondivergent pattern of tissue expression. Fig. $1 \mathrm{~B}$ shows the A1, A 2 and B isoforms isolated by electrophoresis.

Comparisons of Hoplias liver and skeletal muscle unfractionated SMDH and its isolated isoforms revealed both similar and diverging kinetic properties between paralogous homologues (encoded by different gene loci in a species) and the nondivergent A-homologues. Both tissues and isolated isoforms showed similar $\mathrm{pH}$ optima for oxaloacetate reduction (pH 7.5-8.0) (Fig. 2). Statistical analyses of optimum $\mathrm{pH}$ values differed significantly only when liver, and muscle extracts, $\mathrm{A} 1$ and $\mathrm{A} 2$ versus $\mathrm{B}$ isoforms ( $\mathrm{L} \mathrm{x}$ B; M x B; A2 x B; A2 x B, p = 0.0286, respectively), were compared.

Thermal stability of unfractionated sMDH from liver and skeletal muscle extracts is shown in Fig. 3A. When samples were submitted to $50^{\circ} \mathrm{C}$ for various time periods in the absence of substrate or coenzyme, then assayed at $25^{\circ} \mathrm{C}$, the half-life of liver extract, where the thermostable isoform predominates, was about $1 \mathrm{hr}$ while that of skeletal muscle, where the thermolabile isoform predominates, was about $34 \mathrm{~min}$. To determine more precisely the thermal stability of A and B isoforms, partially purified isoforms were also submitted to thermostability tests (Fig. 3B). The half-lives of A1 and A2 isoforms were about $34 \mathrm{~min}$ and $16 \mathrm{~min}$, respectively. In this case, isolated A2 isoforms exhibited differences in thermal stability when compared with liver unfractionated crude extracts from which they were isolated. For the B isoform, the half-life was about $4 \mathrm{~min}$. Significant differences were observed among all the half-lives here obtained except when muscle extracts and A1 isoform values ( $p>0.9999$ ) were compared.

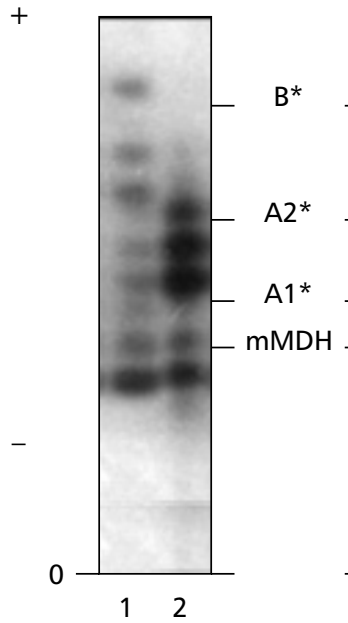

(A)

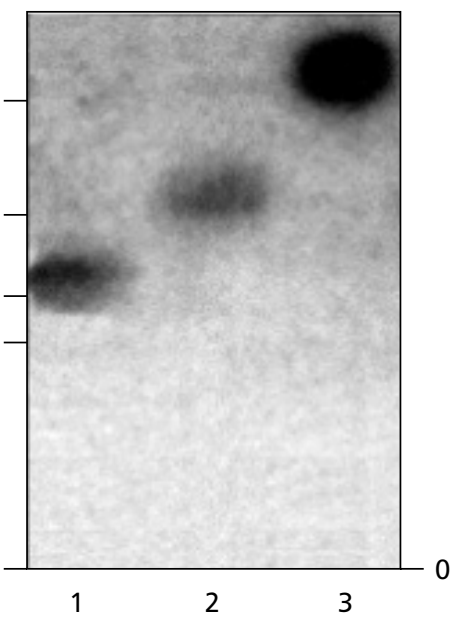

(B)

Fig. 1 - (A) Malate dehydrogenase from liver (1) and skeletal muscle (2) extracts of Hoplias malabaricus. (B) sMDH isolated isoforms: A1 (1), A2 (2) and B (3). mMDH - mitochondrial form; O - origin. 


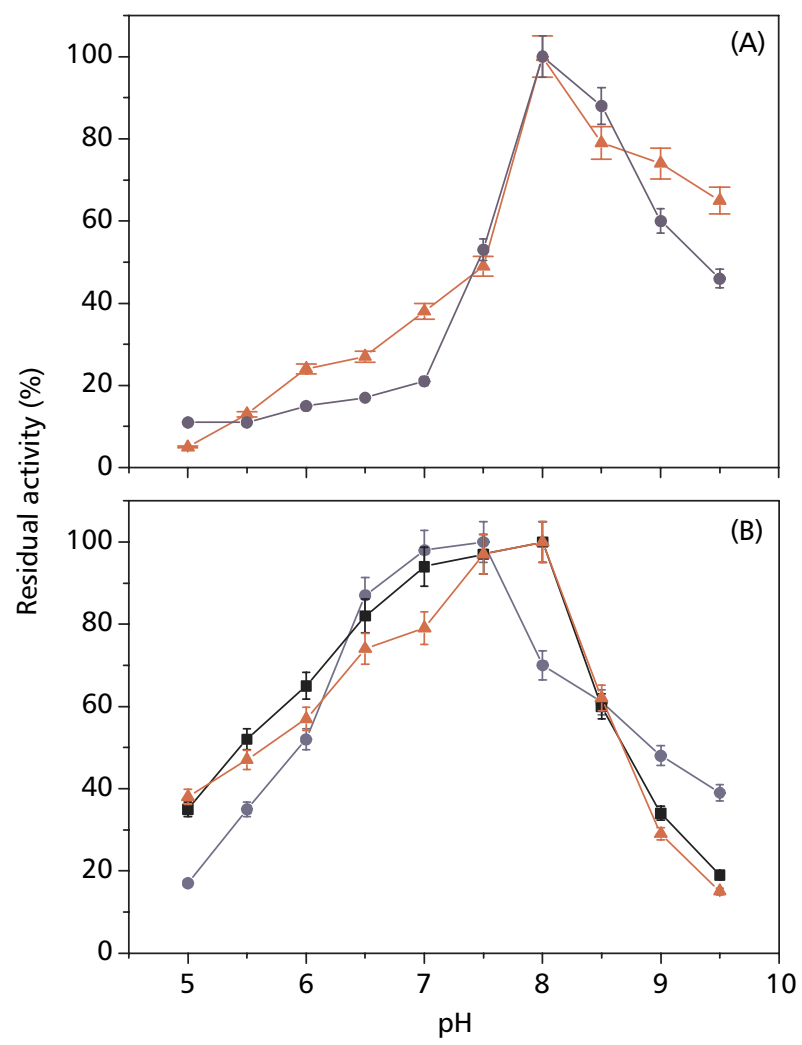

Fig. 2 - (A) The optimal pH of sMDH from liver ( $\mathbf{\Delta}$ ) and skeletal muscle (•) of H. malabaricus. (B) The optimal pH of sMDH from A1 $(\boldsymbol{\Delta})$, A2 $(\bullet)$ and B isoforms $(\bullet)$. Error bars are $95 \%$ confidence intervals for each pH determination.

The responses of both crude extracts and their respective predominant isoforms to various oxaloacetate concentrations are shown in Fig. 4. Optimal substrate concentration differed between isoforms and tissues: A2 isoform has lower optimum concentration for oxaloacetate $\left(0.20 \mathrm{mM} \mathrm{L}^{-1}\right)$ than $\mathrm{A} 1$ and $\mathrm{B}$ isoforms $\left(0.30 \mathrm{mML}^{-1}\right.$ and $\left.0.25 \mathrm{mML}^{-1}\right)$; liver extract has higher optimum concentration for oxaloacetate $\left(0.15 \mathrm{mM} \mathrm{L}^{-1}\right)$ than muscle extract $\left(0.04 \mathrm{mM} \mathrm{L}^{-1}\right)$. Statistical analyses of optimal substrate concentration only differ significantly when liver versus A2 isoform ( $\mathrm{p}=0.1143)$, and $\mathrm{A} 1$ and $\mathrm{A} 2$ versus $\mathrm{B}$ isoforms $(\mathrm{p}=0.1143$ and $\mathrm{p}=$ 0.200 , respectively) were compared. $\mathrm{Km}$ of oxaloacetate was higher for liver extracts $(0.050$ $\left.\mathrm{mM} \mathrm{L}^{-1}\right)$ and their $\mathrm{A} 1$ and $\mathrm{A} 2$ isoforms $(0.061$ $\left.0.042 \mathrm{mM} \mathrm{L}^{-1}\right)$ than for muscle extracts $(0.014 \mathrm{mM}$ $\left.\mathrm{L}^{-1}\right)$ and their B isoform $\left(0.024 \mathrm{mM} \mathrm{L}^{-1}\right)$.

All the statistical analyses of $K \mathrm{~m}$ values showed significant differences.

\section{DISCUSSION}

New enzymes can be formed since the presence of redundant copies allows one sequence to mutate freely and acquire new catalytic functions. The duplicate genes may have two kinds of homology: orthology and paralogy. Duplicate genes related by speciation are orthologous and genes related by regional events or duplication of a single gene through ploidy changes are paralogous (Ferris, 1984). The homologies of duplicated genes can be inferred from measurements of $\mathrm{pH}$ optima, heat stability and other kinetic properties like optimum substrate concentration or $K \mathrm{~m}$ values.

Two different processes lead to gene duplication. Firstly, a polyploidization where the entire genome is duplicated may occur simultaneously. Secondly, duplication in tandem, involving a single gene locus or several gene loci of a group in linkage, results in gene duplication. 


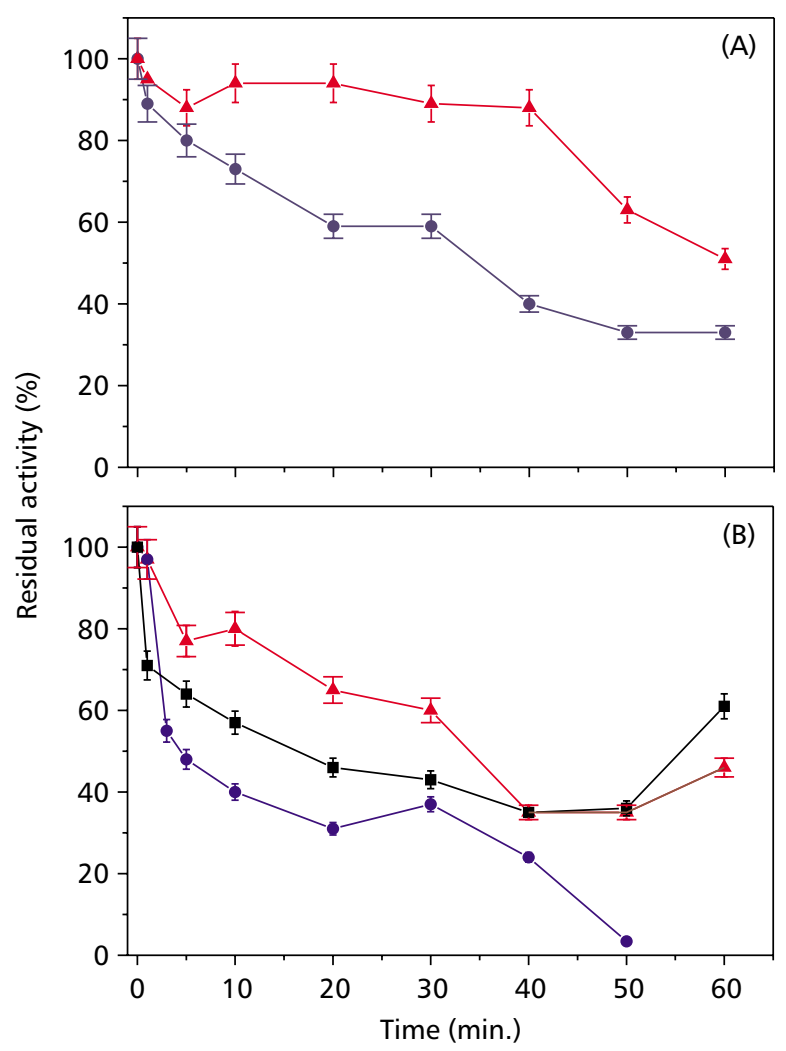

Fig. 3 - (A) Thermal inactivation of MDH from liver $(\boldsymbol{\Delta})$ and skeletal muscle $(\bullet)$ of H. malabaricus extracts. (B) Thermal inactivation of sMDH from A1 $(\boldsymbol{\Delta}), \mathrm{A} 2(\boldsymbol{\nabla})$ and B isoforms $(\bullet)$. Error bars are $95 \%$ confidence intervals for each temperature determination.

According to Ohno (1970), these two processes complement each other in producing significant gene duplication. According to Bertollo et al. (1986), the Erythrinidae family has shown greatly varying karyotypes, with diploid ranging from 39 to 42 chromosomes and variable chromosomal rearrangements during its evolutionary history. Therefore, in Hoplias, gene duplication could have arisen by tandem duplication (Monteiro et al., 1991, 1998; Aquino-Silva et al., 1997).

Generally, specific activity, thermostability and other kinetic enzyme properties vary with $\mathrm{pH}$ fluctuation. De Luca et al. (1983), studying adaptative features of sMDH in the subtropical fish, Astyanax fasciatus, showed that its isoforms had different $\mathrm{pH}$ optima for oxaloacetate reduction, being higher for B-thermolabile (7.8 versus 6.5). Otherwise, in comparative studies of sMDH paralogous homologues of four species of Pacific barracudas adapted to different temperatures, Lin \& Somero (1995b) obtained, for both isoforms, in the direction of oxaloacetate reduction, similar optima $\mathrm{pH}$ (7.6 and 7.7). For Hoplias, optimum $\mathrm{pH}$ obtained with muscle and liver extracts, and A1 and A2 isoforms (8.0) was significantly different of the obtained with B isoforms (7.5).

Temperature adaptation by the two paralogous soluble MDH gene loci, where the $S M D H-A^{*}$ encodes a thermostable and the $s M D H-B^{*}$ a thermolabile isoform (Schwantes \& Schwantes, 1982a, b; De Luca et al., 1983; Coppes et al., 1987; Farias \& Almeida-Val, 1992; Lin \& Somero, 1995a, b; Caraciolo et al., 1996) was also detected in $H$. malabaricus when its unfractionated $\mathrm{sMDH}$ was repeatedly incubated at $58^{\circ} \mathrm{C}$, electrophoresed and stained for MDH activity (Monteiro et al., 1991, 1998; Aquino-Silva et al., 1997). 


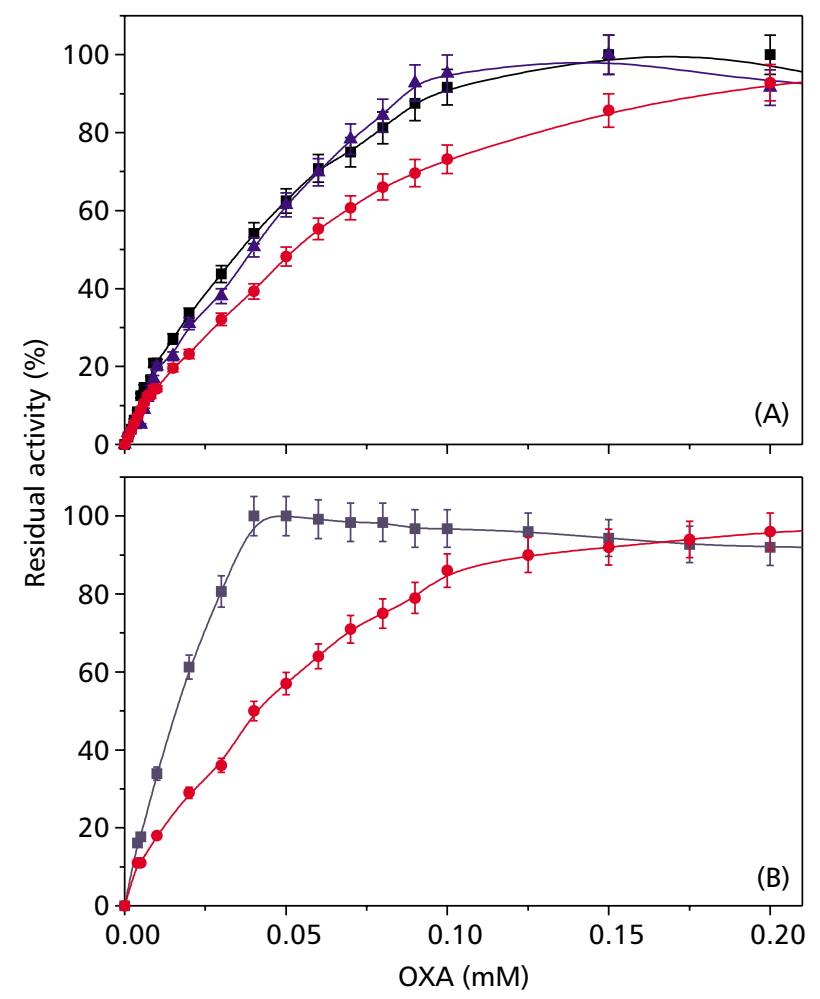

Fig. 4 - (A) MDH saturating curves (oxaloacetate reduction) from H. malabaricus. Liver $(\mathbf{A}), \mathrm{A} 1(\bullet)$ and A2 isoforms

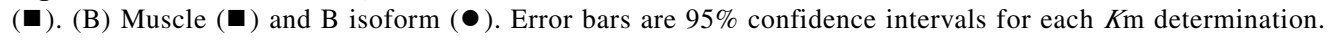

However, when isolated A isoforms were incubated to $50^{\circ} \mathrm{C}$, for $10-60 \mathrm{~min}$, in the absence of substrate or coenzyme, and assayed for residual activity, they did not exhibit the thermal stability observed through electrophoresis. Comparative studies of thermostable and thermolabile sMDH isoforms of barracuda species from different physiological temperature ranges revealed similar kinetic properties for orthologous and varying for paralogous homologues (Lin \& Somero, 1995a, b). According to these authors, the absence of thermolabile isoform in equatorial barracuda (Sphyraena ensis) could occur through two mechanisms: loss of the gene (or functional form of the gene) encoding this isoform, or repression of gene transcription at high temperatures. Thus, if the thermolabile isoform is not required physiologically, the gene encoding this isoform may effectively be lost. However, Farias \& AlmeidaVal (1992) and Caraciolo et al. (1996) studying the sMDH of Amazon fishes detected the product of the thermolabile locus. Farias \& Almeida-Val
(1992) also showed a recent duplication of $s M D H$ $B^{*}$ in Amazon cichlids. Schwantes \& Schwantes (1982a), studying the adaptative features of sMDH loci from temperate estuarine fish, Leiostomus xanthurus (habitat temperature range $5-30^{\circ} \mathrm{C}$ ), showed that A and B subunits occur in different tissues at different levels which may be altered by environmental temperature fluctuation. On the other hand, Lin \& Somero (1995a, b) studying the eurythermal Gillichthys mirabilis (habitat temperature range $9-38^{\circ} \mathrm{C}$ ), showed that the two isoforms of sMDH vary in ratio seasonally and as a result of acclimation. According to these authors, the findings suggest that temperature can affect one or more of the processes that establish sMDH isozyme ratios, like gene transcription or protein degradation.

Thermostability tests realized with liver extracts, tissue in which Klebe's tests showed the presence of 16 A subunits for 1 of B according to Aquino-Silva et al. (1997), showed the enzyme halflife with 60 minutes of incubation. However, when 
the isolated A1 and A2 isoforms were incubated, their half-lives were 34 and 16 minutes, respectively. These results showed that the A isoforms could not be seen as the L. xanthurus (Schwantes \& Schwantes, 1982a, b) or the Astyanax fasciatus (De Luca et al., 1983) thermostable isoforms (half-lives were well over $1 \mathrm{hr}$ ) and showed the first divergence between them: A2 isoform was significantly more thermolabile than A1 isoform. For skeletal muscle extracts, tissue where the $s M D H-B^{*}$ predominates ( 2 B subunits for 1 A subunit) showed a 34 min and its specific B isoform a 4 min half-lives. According to Lin \& Somero (1995b), some characteristics are conserved among orthologous homologues of each sMDH isoform. Comparisons of orthologous homologues with respect to thermostability showed that while $\mathrm{A}$ isoforms of $H$. malabaricus could not be characterized as thermostable isoform, B could be thermolabile.

Studies of orthologous homologues of proteins from species adapted to different temperatures have revealed strong conservation of many kinetic properties (like $\mathrm{Km}$ substrate or cofactor) within physiological temperature ranges (Somero, 1978; Hochachka \& Somero, 1984; Coppes \& Somero, 1990; Lin \& Somero, 1995a, b; Aquino-Silva et al., 1997). In eurythermal ectotherms especially species with standing high temperatures, effects of temperature on $K \mathrm{~m}$ values are generally much smaller than those noted for homologous enzymes of stenothermal species (Baldwin \& Aleksiuk, 1973; Coppes \& Somero, 1990; Somero, 1981). According to Lin \& Somero (1995b), a mechanism by which a eurythermal species might conserve enzymatic function over a wide temperature range is the presence of multiple forms like the sMDH isoforms; not only the two paralogous sMDH differ in thermal stability, but temperature effects on $K \mathrm{~m}$ values differ among isoforms. Therefore, adaptation to temperature by $\mathrm{sMDH}$ in teleosts differs from the pattern obtained for A4-LDH in barracudas (Lin \& Somero, 1995b). While in A4-LDH the $K \mathrm{~m}$ conservation at physiological temperatures came about through evolutionary change in the aminoacid sequence of orthologous homologues, for sMDH conservation may result from altering the ratio of thermostable and thermolabile paralogous isozymes (Lin \& Somero, 1995b). In the present paper, the $K \mathrm{~m}(\mathrm{OXA})$ values obtained for both $\mathrm{A} 1$ and $\mathrm{A} 2$ isoform, isolated from liver extract (16A: 1B subunit ratio), were 1.45 higher for A1 isoform (0.061 mM x $0.042 \mathrm{mM})$, and 2.54 lower than that obtained for $\mathrm{B}$ isoform (0.061 mM x $0.024 \mathrm{mM})$. When we compare the $\mathrm{Km}$ isoform values with those obtained for crude extracts in skeletal muscle the $K \mathrm{~m}$ values are similar to the specific isoform $\mathrm{B}$. Also the $K \mathrm{~m}$ values for liver extracts are similar to the $\mathrm{A} 1$ and $\mathrm{A} 2$ isoforms. ln both case, $K \mathrm{~m}$ values agree with the contributions of gene duplication detected by Aquino-Silva et al. (1997). Also, comparing the Km values shown by $H$. malabaricus with those obtained from other fishes, we suggest that the A1 isoform of Hoplias could be an orthologous homologues of the A isoform from Geophagus brasiliensis (Aquino-Silva et al., in prep), A. fasciatus (De Luca et al., 1983), L. xanthurus (Schwantes \& Schwantes, 1982b), as well as from different species of Pacific barracudas (Lin \& Somero, 1995b). The Hoplias B isoform could also be an orthologous homologues of the B1 isoform from $G$. brasiliensis (Aquino-Silva et al., in prep), and $\mathrm{B}$ isoform from A. fasciatus (De Luca et al., 1983), L. xanthurus (Schwantes \& Schwantes, 1982b), as well as from the barracudas (Lin \& Somero, 1995b).

According to Bailey et al. (1970), the distribution of sMDH isoforms in ectotherms showed certain tissue specificity but its physiological significance has not yet been established. For diverse sMDH isoforms, the less anodic, generally the $\mathrm{A}$ isoform is found to some extent in all tissues and $\mathrm{B}$ isoform predominates in skeletal muscle (Clayton et al., 1975). Three different biological functions have been proposed for sMDH: gluconeogenesis, lipogenesis and malate-aspartate shuttle during aerobic glycolysis. Since these processes are carried out differently by different tissues, this might be a possible explanation for the different activities of multiple forms of $\mathrm{MDH}$. Their presence or absence would be due to different physiological and metabolic roles. Physiological activities of organisms are influenced by environmental factors such as temperature, dissolved gases, light, pressure, salinity, etc. Thus, development of homeokinetic mechanisms in many organisms could minimize the effects of parametric fluctuation. According to Shaklee et al. (1977), metabolic reorganization during thermal acclimation can be and probably is a tissue-specific process. According to Coppes et al. (1987), the presence of the A isoform in most tissues, more thermostable and more resistant to substrate than 
the $\mathrm{B}$ ones could be correlated with temperature. Both sMDH isoforms may differently affect the carbon flow balance through glycolysis and gluconeogenesis. When temperature increases, metabolic activity increases too, and oxaloacetate would be reduced to malate by A isoform, yielding NAD, which would be used by glyceraldehyde3-phosphate dehydrogenase, favoring the glycolytic direction. In this case, in the characiform $H$. malabaricus, the presence of the A2 isoform arisen by gene duplication, would broaden this metabolic pathway, once it showed lower $K \mathrm{~m}$ value, consequently higher substrate affinity than the A1 isoform.

Acknowledgments - Research supported by Conselho Nacional de Desenvolvimento Científico e Tecnológico (CNPq), and Fundação de Amparo à Pesquisa do Estado de São Paulo (FAPESP). The authors wish to thank Dr. Paula Ann Matvienko-Sikar, who critically reviewed this manuscript. Publication supported by FAPESP.

\section{REFERENCES}

AQUINO-SILVA, M. R., SCHWANTES, M. L. B. \& SCHWANTES, A. R., 1997, The multiple soluble malate dehydrogenase of Hoplias malabaricus (Characiformes). Exp. Biol. Online, 2: 18.

BAILEY, G. J., COCKS, G. T. \& WILSON, A. C., 1969, Gene duplication in fishes: malate dehydrogenase of salmon and trout. Biochem. Biophys. Res. Comm., 34: 605-612.

BAILEY, G. S., WILSON, A. C., HALVER, J. E. \& JOHNSON, C. L., 1970, Multiple forms of supernatant malate dehydrogenase in salmonid fishes: biochemical, immunological and genetic studies. J. Biol. Chem., 245: 5927-5940.

BALDWIN, J. \& ALEKSIUK, M., 1973, Adaptation of enzymes to temperature: lactate and malate dehydrogenase from platypus and echidna. Comp. Biochem. Physiol. 44B: 367-370.

BERTOLLO, L. A. C., MOREIRA-FILHO, O. and GALETTI Jr., P. M., 1986, Cytogenetics and taxonomy considerations based on chromosome studies of freshwater fish. J. Fish Biol., 28: 153-159.

CARACIOLO, M. C., VAL, A. L. \& ALMEIDA-VAL, V. M. F., 1996, Malate dehydrogenase polymorfism in amazon curimatids (Teleostei: Curimatidae): Evidence of an ancient mutational event. Rev. Bras. Genet., 19: 57-64.

CLAYTON, J. W., HARRIS, R. E. K. \& TRETIAK, D. N., 1975 , Identification of supernatant and mitochondrial isozymes of malate dehydrogenase on electropherograms applied to the taxonomic discrimination of walleye (Stizolection vitreum vitreum, Sanger) and suspected interspecific hybrid fishes. J. Fish. Res. Bd. Can., 30: 927-938.
COPPES, Z. L., SCHWANTES, M. L. B. \& SCHWANTES, A. R., 1987, Adaptative features of enzymes from family Sciaenidae (Perciformes). I. Studies on soluble malate dehydrogenase (sMDH) and creatine kinase (CK) of fishes from the South Cost of Uruguay., Comp. Biochem. Physiol. 88B: 203-210.

COPPES, Z. L. \& SOMERO, G. N., 1990, Temperatureadaptative differences between the M4 lactate dehydrogenases of stenothermal and eurythermal sciaenid fishes. J. Exp. Zool., 254: 127-131.

DE LUCA, P. H., SCHWANTES, M. L. B. \& SCHWANTES, A. R., 1983, Adaptative features of ectothermic enzymes. IV. Studies on malate dehydrogenase of Astyanax fasciatus (Characidae) from Lobo Reservoir (São Carlos, São Paulo, Brasil). Comp. Biochem. Physiol., 47B: 315-324.

FARIAS, I. P. \& ALMEIDA-VAL, V. M. F., 1992, Malate dehydrogenase (sMDH) in amazon cichlid fishes: evolutionary features. Comp. Biochem. Physiol., 103B: 939-943.

FENERICH-VERANI, N., SCHWANTES, M. L. B. \& SCHWANTES, A. R., 1990, Patterns of gene expression during Prochilodus scrofa (Characiformes: Prochilodontidae) embryogenesis - II. Soluble malate dehydrogenase. Comp. Biochem. Physiol., 97B: 247-255.

FERRIS, S. D., 1984, Tetraploidy and the evolution of the catostomid fishes. In: J. B. Turner (ed.), Evolutionary genetics of fishes. Plenum, New York.

HOCHACHKA, P. W. \& SOMERO, G. N., 1984, Biochemical adaptation, Princeton, New Jersey.

KLEBE, R. J., 1975, A simple method for the quantification of isozyme patterns. Biochem. Genet., 13: 805-812.

LIN, J. J. \& SOMERO, G. N., 1995a, Temperature-dependent changes in expression of thermostable and thermolabile isozymes of cytosolic malate dehydrogenase in the eurythermal goby fish Gillchthys mirabilis. Physiol. Zool., 68: 114-128.

LIN, J. J. \& SOMERO, G. N., 1995b, Thermal adaptation of cytoplasmic malate dehydrogenase of Eastern Pacific barracuda (Sphyraena sp.): the role of differential isoenzyme expression. J. Exp. Biol., 198: 551-560.

MONTEIRO, M. C., SCHWANTES, M. L. B. \& SCHWANTES, A. R., 1991, Malate dehydrogenase in subtropical fish belonging to the orders Characiformes, Siluriformes and Perciformes. I. Duplicate gene expression and polymorfism. Comp. Biochem. Physiol., 100B: 381-390.

MONTEIRO, M. C., SCHWANTES, M. L. B., SCHWANTES, A. R. \& AQUINO-SILVA, M. R., 1998, Thermal stability of soluble malate dehydrogenase isozymes of subtropical fish belonging to the orders Characiformes, Siluriformes and Perciformes. Genet. Mol. Biol., 21: 191-199.

OHNO, S., 1970, Evolution by gene duplication. SpringerVerlag, New York.

SCHWANTES, M. L. B. \& SCHWANTES, A. R., 1977, Eletrophoretic studies on polyploid amphibians. III. Lack of locus duplication evidences through tetraploidization. Comp. Biochem. Physiol., 57B: 341-351. 
SCHWANTES, M. L. B. \& SCHWANTES, A. R., 1982a, Adaptative features of ectothermic enzymes. I. Temperature effects on the malate dehydrogenase from a temperate fish, Leiostomus xanthurus. Comp. Biochem. Physiol., 72B: 49-58.

SCHWANTES, M. L. B. \& SCHWANTES, A. R., 1982b, Adaptative features of ectothermic enzymes. II. The effects of acclimation temperature on the malate dehydrogenase of the spot, Leiostomus xanthurus. Comp. Biochem. Physiol., 72B: 59-64.

SHAKLEE, J. B., ALLENDORF, F. W., MORIZOT, D. C. F. \& WHITT, G. S., 1989, Genetic nomenclature for protein coding loci in fish: Proposed Guildelines. Transac. Amer. Fish. Soc., 118: 218-227.

SHAKLEE, J. B., CHRISTIANSEN, J. A., SIDELL, B. D., PROSSER, C. L. \& WHITT, G. S., 1977, Molecular aspects of temperature acclimation in fish: contributions of changes in enzyme activities and isozyme patterns to metabolic reorganization in the green sunfish. J. Exp. Zool., 201: 1-20.
SOMERO, G. N., 1978, Temperature adaptation of enzymes: biological optimization through structure-function compromises. Ann. Rev. Ecol. Syst., 9: 1-29.

SOMERO, G. N., 1981, pH temperature interaction on proteins. Principles of optimal $\mathrm{pH}$ and buffer system design. Marine Biol. Lett., 2: 163-178.

VAL, A. L., SCHWANTES, A. R., SCHWANTES, M. L. B. \& DE LUCA, P. H., 1981, Amido hidrolisado de milho com suporte eletroforético. Ciência e Cultura, 33: 992996.

WHITT, G. S., 1970, Genetic variation of supernatant and mitochondrial malate dehydrogenase isozymes in the Teleost Fundulus heteroclitus. Experientia, 26: 734-736.

ZAR, J. H., 1974, Biostatistical analysis. W. D. McElroy \& C. P. Swanson (eds.), Prentice-Hall, New Jersey. 